\title{
PROFITABILITY OF FAMILY FARMS DIRECTED AT CROP PRODUCTION $^{1}$
}

\author{
Petar Munćan², Saša Todorović ${ }^{3}$ Mihajlo Munćan ${ }^{4}$
}

\begin{abstract}
Summary
The efficiency in crop production depends on, on the one hand, achieved yields and selling prices (production value) and, on the other hand, on the incurred production costs. These data suggest different economic indicators which indicate the efficiency of farm operations. Data on the basic parameters of production were collected using the method of survey, which was conducted during the five-year period (2009-2013) on the selected 40 family farms $(<100 \mathrm{ha})$, divided into five groups, each consisting of 8 farms, oriented exclusively towards crop production in the region of two municipalities in the South Banat District. Production efficiency and rational usage of available resources of observed family farms were measured by calculating their profit including state incentives for agriculture and evaluating their own resources engaged in the production.
\end{abstract}

Key words: profit, family farm, crop production, opportunity costs.

JEL: $Q 12, Q 15$

\section{Introduction}

The value structure of agricultural production in Serbia is dominated by plant production, with an average share of more than $65 \%$, ranging from $59.8 \%$ to $70.1 \%$ in the period of 2003-2012. Crop production, as the most important branch of plant production, takes place averagely on the area of over 2.7 million of hectares per annum, while its share in the value structure of total agricultural production, in the observed period, ranged from $46.8 \%$ to $59.2 \%$. About $82.7 \%$ of this production takes place on the family farms, which according

1 The paper is a result of the research conducted within the project of the Ministry of Education, Science and Technological Development of the Republic of Serbia No. 179028, entitled „Rural labour market and rural economy of Serbia - diversification of income and reduction of rural poverty".

2 Petar Munćan, Ph.D., Full Professor, University of Belgrade, Faculty of Agriculture, Nemanjina Street No. 6, 11080 Zemun, Serbia, Phone: +381 11 2615 315/ext. 413, E-mail: muncan@agrif.bg.ac.rs

3 Saša Todorović, Teaching Assistant, University of Belgrade, Faculty of Agriculture, Nemanjina Street No. 6, 11080 Zemun, Serbia, Phone: +381 11 2615 315/ext. 406, E-mail: sasat@agrif.bg.ac.rs

4 Mihajlo Munćan, Teaching Assistant, University of Belgrade, Faculty of Agriculture, Nemanjina Street No. 6, 11080 Zemun, Serbia, Phone: +381 112615 315/ext. 406, E-mail: mmuncan@agrif.bg.ac.rs

EP 2014 (61) 3 (575-585) 
to the 2012 agricultural census amount to 628,552 , and they own more than 2.5 million of hectares of arable land. Regarding the crops, the vast majority of production of the most important field crops occurs on the family farms: about $88 \%$ of the total maize production, about $73 \%$ of wheat production, about $65 \%$ of sunflower production and about $50 \%$ of soya bean and sugar beet production (Božić and Munćan, 2007). The vast majority of crop production of the Republic of Serbia occurs in the region of AP Vojvodina. About 52\% of the cereal-growing area and more than $92 \%$ of the industrial crop-growing area of Serbia are located in this region (Bošnjak and Rodić, 2010; Bošnjak and Rodić, 2011; Munćan et al., 2010). Family farms represent the most important holder of organising crop production in AP Vojvodina. According to the 2012 agricultural census, the number of these farms in AP Vojvodina amounted to 146,269 , which makes $23.3 \%$ of the total number of farms in the Republic of Serbia. However, family farms in AP Vojvodina are mainly small, since the farms smaller than 2 ha make $46.9 \%$ of the total number of farms and use less than $3.1 \%$ of arable areas. The farms larger than 10 ha amount to $17.5 \%$ of the total number of farms and use $82.8 \%$ of arable areas in AP Vojvodina. Size of these farms is one of the decisive factors of the efficiency of agriculture. The agriculture of Serbia is traditionally characterised by the unfavourable farm size, which particularly applies to family farms which as the most numerous entities in agriculture dominantly determine its total development (Bogdanov and Božić, 2005). It is stated that the persistence of small farms may be associated with the provision of generous subsidies, which are negatively related to farms' technical efficiency but positively related to their profitability. Subsidies reduce technical and economic efficiency, but favour allocative efficiency and profitability (Bojnec and Latruffe, 2013).

Given the crucial importance of the farm size for the efficiency of operations in agriculture, it can be concluded that with such unfavourable farm size it is difficult to be competitive in the market in the conditions of increasingly strong competition. The process of integrations in the World Trade Organization and the European Union (EU) in addition to opening new large markets requires a significant increase in productivity and competitiveness. In this regard, market liberalisation occurs as a major driving force of innovation and increase in competitiveness (Bogdanov et al., 2004). Structural change also provides the possibility of increasing the competitiveness and efficiency of the entire agricultural sector through a better allocation of productive factors. Amongst the productive factors, land is the one that most often limits farm development (Bartolini and Viaggi, 2013). In this respect, the possibility of family farms to survive in the future, especially when entering the EU, is directly linked to their ability to make the best possible use of available resources. Bearing that in mind, the subject of research in this paper is the profitability of family farms directed at crop production from the region of AP Vojvodina.

The paper is aimed at determining the extent to which the farm size, expressed as the utilised area, and the size of land area rented influences the level of the profitability achieved on these farms. 


\section{Method of research and sources of data}

Due to the unavailability of adequate statistical data for a more comprehensive analysis of the impact of the size of crop production oriented family farm on the achieved profitability at the level of the Republic of Serbia, more detailed examinations in this paper are based on data from the survey. The survey was conducted on the 40 selected family farms directed exclusively at crop production from the area of two municipalities in the South Banat District. The farms are, considering the size (the area of utilised arable land), divided into five groups: up to 10 ha, 10-20 ha, 20-30 ha, 30-50 ha and 50-100 ha. When selecting the farms, the tendency was to have an even distribution across the mentioned groups therefore each group comprised 8 farms.

The data collected by means of the survey are related to the following elements:

- production capacities (resources) of farms (utilised arable land (owned or rented), commercial buildings, mechanisation and labour force),

- yield per capacity unit of represented enterprises (maize, wheat, sunflower, soya bean and sugar beet),

- production value and production costs in terms of basic elements and

- main technical and technological parameters.

The decision to include the family farms of the size of up to 100 ha of arable land in the sample for this research derives from the fact that:

- the mentioned farms, according to the 2012 agricultural census, make use of $82.8 \%$ of arable land in AP Vojvodina; and

- the main condition for the eligibility for any kind of state incentives in agriculture, besides entering in the Register of agricultural farms, is that the farm size does not exceed 100 ha of arable land.

The analysis of operations of family farms directed at crop production includes the analysis of the production value, production costs and profit. Profit is calculated as the difference of realised revenues and total costs. Realised revenues include revenues from the sale of agricultural products and state incentives for crop production, while total costs include the costs of materials, services, labour, land rent and capital. All indicators in this paper were calculated on the basis of empirical data collected by using the survey. In order to avoid the effects of a more significant fluctuation of prices (input and output) and natural (meteorological) conditions on the obtained results in the production of crops when calculating financial indicators, the five-year price averages were used (2009-2013). Based on the economic parameters, using the appropriate form of the function, the size of farms in which the realised profit with and without state incentives for agriculture is determined as well as the size of farms in which the opportunity costs of their own land are covered.

\section{Results and discussion}

The average area of arable land cultivated by family farms surveyed was 38.79 ha and ranged from 9.31 ha to 94.74 ha. Using only the arable land by the investigated family 
farms represents a favourable prerequisite for the organization of intensive crop production. The smallest farms use only their own arable land, whereas in the case of the largest farms rented land makes $66 \%$ of the total arable land used (Graph 1).

Graph 1. Used arable land owned and rented for the surveyed farms of different sizes

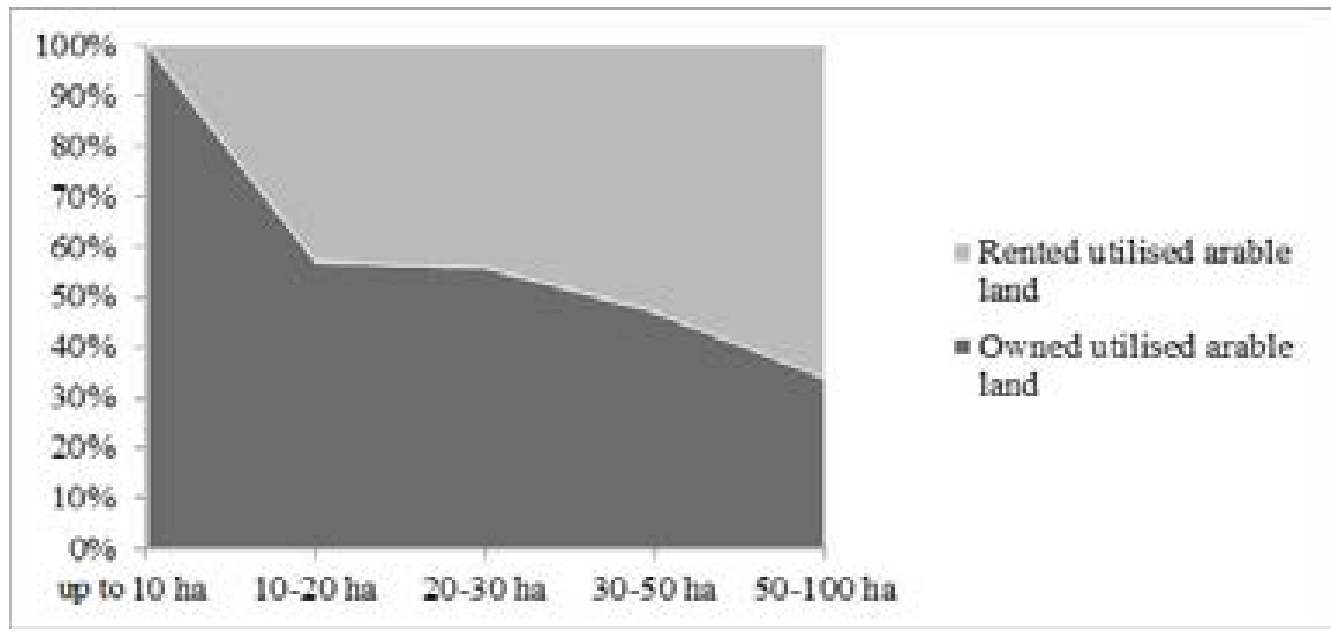

Source: Authors' calculation based on the survey data.

Cereals (wheat and maize) represent a dominant group of crops on the investigated family farms. Their share in the sowing structure of arable land ranges from $59.0 \%$ in the case of the largest farms to $81.0 \%$ in the case of the smallest farms. As regards the distribution of industrial crops (sunflower, soya bean, sugar beet), a certain tendency can be observed. Namely, the share of this group of crops rises when the used arable area increases. The smallest share of industrial crops is noticed in the case of the smallest farms, only $19 \%$, whereas this share in the case of the largest farms amounts to $41 \%$ in the sowing structure of the arable land. This tendency can be primarily explained by the fact that the larger farms are better equipped with agricultural mechanisation which allows them simpler and more rational realisation of the technology of production of industrial crops, particularly sugar beet.

Increasing the farm size and changing the structure of crop production, that is, increasing the share of industrial crops in the sowing structure of arable land, the production value per ha shows the tendency of growth (Munćan et al., 1996). Thus, for example, in comparison with the smallest farm size, the realised average production value per ha is higher in the case of the largest farms, even by $25.53 \%$. In addition, the income per an active farmer in the case of the largest farms (of the size of $100 \mathrm{ha}$ ) is more than fivefold higher than in the case of the smallest farms, whereas in comparison with the medium-sized farms of the size of up to 50 ha, it is almost twofold higher (Munćan, 2011).

On the other hand, the changes that occurred on the market of the primary agricultural products and inputs for agricultural production in the observed period had a huge impact on the input level. Under the existing conditions, many family farms have not been able to secure the 
necessary funds which resulted in the reduction of the input level. Budget constraint has been found to be an important factor limiting farms' use of inputs not only in developing countries, but also in developed economies (Blancard et al., 2006). In this regard, potential savings in mineral fertilizers applied by some family farms in case of a lack of financial means and favourable sources of financing cannot be considered as rationalisation, because a reduced investment in this segment reflected negatively on profitability of production since it is well known that the quantity of applied mineral fertilizer is one of the factors which significantly influences the realised yield. Example of family farms where full agro-technical measures were applied, which included application of adequate quantities of mineral fertilizer, even in conditions of the high purchasing price of this input, has economic justification considering its contribution to the increase of profitability of the production (Munćan and Božić, 2013; Todorović et al., 2010; Todorović and Filipović, 2010). The lower level of intensity of production as a result of lack of resources leads to a significant reduction in income generated by certain producers. Therefore, it can be said that financial constraints and credit market imperfections are major obstacles to investment, growth and poverty reduction in transition and developing countries (Dries and Swinnen, 2010). Bearing that in mind, in order to obtain a picture as complete as possible, the production value, variable and fixed costs for farms of different sizes are provided (Table 1).

Table 1. The average production value, variable and fixed costs per ha calculated in terms of the average prices for the period of 2009-2013 (base indices - farms of the size of up to 10 ha $=100$ )

\begin{tabular}{|l|c|c|c|c|c|}
\hline \multirow{2}{*}{ Indicators } & \multicolumn{5}{c|}{ Farm size (ha) } \\
\cline { 2 - 6 } & $\begin{array}{c}\text { up to } \mathbf{1 0} \\
\text { ha }\end{array}$ & $\mathbf{1 0 - 2 0}$ ha & $\mathbf{2 0 - 3 0}$ ha & $\mathbf{3 0 - 5 0}$ ha & $\begin{array}{c}\mathbf{5 0 - 1 0 0} \\
\text { ha }\end{array}$ \\
\hline Production value (RSD per ha) & $100.0 \%$ & $102.6 \%$ & $103.1 \%$ & $112.8 \%$ & $125.5 \%$ \\
\hline Variable costs (RSD per ha) & $100.0 \%$ & $102.1 \%$ & $106.1 \%$ & $115.7 \%$ & $123.1 \%$ \\
\hline $\begin{array}{l}\text { Fixed costs without the costs of renting land } \\
\text { (RSD per ha) }\end{array}$ & $100.0 \%$ & $64.8 \%$ & $74.1 \%$ & $64.9 \%$ & $53.7 \%$ \\
\hline $\begin{array}{l}\text { Fixed costs with the costs of renting land } \\
\text { (RSD per ha) }\end{array}$ & $100.0 \%$ & $130.6 \%$ & $142.3 \%$ & $146.5 \%$ & $154.7 \%$ \\
\hline
\end{tabular}

Source: Authors`calculation based on the survey data.

It is evident that the variable costs per ha in the case of the largest farms are higher by $23.1 \%$ compared to the smallest farms, which indicates a higher input level on the largest farms compared with the smallest ones, which results in a higher realised average value of production per ha in the case of the largest farms.

As regards the fixed costs, it is well known pattern that their total amount at the level of farm does not change when the change in the level of production or degree of capacity use occurs, that is, their total amount remains the same regardless of the amount of products produced or services rendered (Gogić, 2009). However, their amount per ha of arable area significantly decreases in the case of the increase in farm size. Hence, the fixed costs calculated per ha of arable area in the case of the largest surveyed farms are lower by $46.3 \%$ in comparison with the smallest surveyed farms. However, the decline in the amount of 
fixed costs per ha which occurs with increasing farm size is offset by the high costs of renting agricultural land, which rise with the increase in the farm size. More precisely, the costs of renting calculated per ha of total used arable land soar with increasing the farm size because the largest farms have a higher share of land rented compared to smaller farms. This causes the amount of fixed costs with the costs of renting land per ha of arable area on the largest farms to be higher by $54.7 \%$ compared with the smallest surveyed farms.

Based on the aforementioned, it can be concluded that the increase in the size of family farms and the change in the structure of crop production cause relatively high rate of the growth in production value and variable costs per hectare of arable area (input level), as well as a significant decrease in fixed costs (excluding the costs of renting land) per ha of arable land.

The trend of the previously discussed indicators of surveyed family farms depending on farm size affects the profitability of their business operation. In addition, the analysis of profitability is sensitive to the presence or absence of state incentives for agriculture. In this respect, family farms that are profitable can cease to be profitable when state incentives for agriculture are excluded from the calculation.

When including state incentives for agriculture, all surveyed farms (100\%) are profitable. This could lead to a simple conclusion about the profitability of family farms directed at crop production. However, the fact is that when state incentives are deducted, it can be seen that the percentage of profitable family farms is significantly reduced. In that case, the only profitable farms are those of the size of up to 13.38 ha and farms of the size of over 86.06 ha, the farms between these two sizes are unprofitable (Graph 2).

Graph 2. Profitability of the surveyed farms with and without state incentives for agriculture

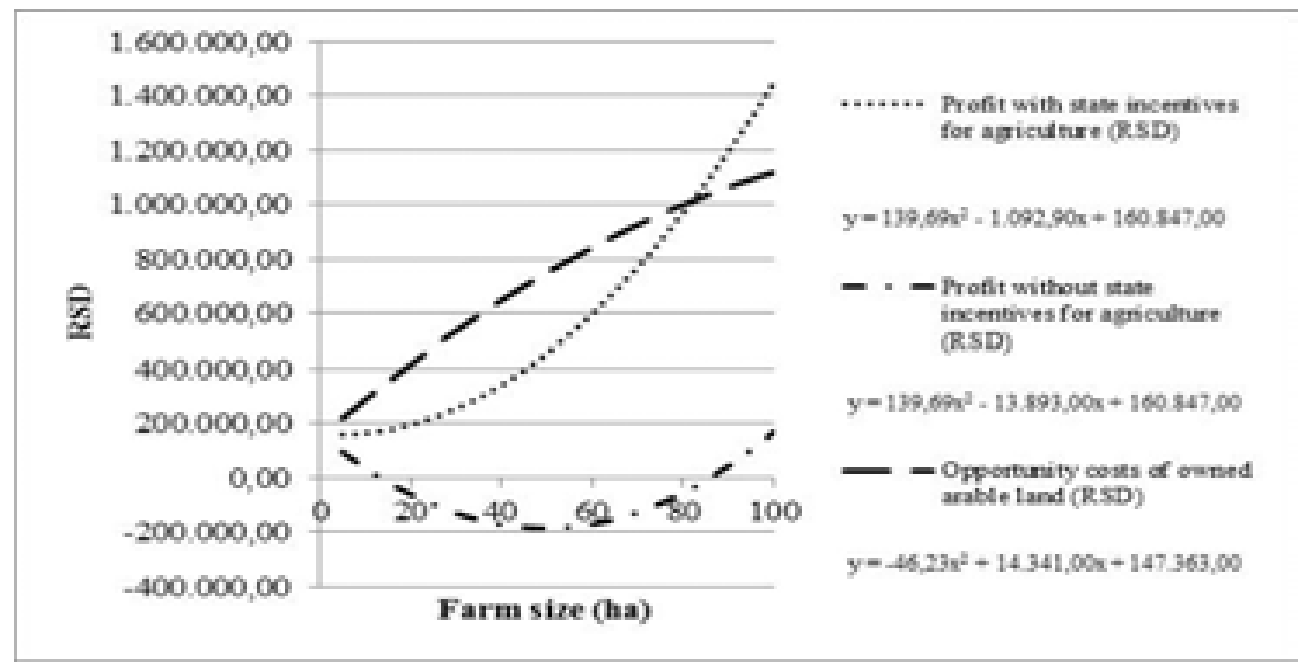

Source: Authors`calculation based on the survey data. 
Given that each factor of production should make a return at the level of opportunity costs, the costs of their own land were evaluated by using regional averages. When it comes to its own land, if the family farm is a combination of land rented and owned, the amount paid for rent is applied to the land owned by assuming that the land rented and owned in the close vicinity, and therefore is of similar quality. If a family farm does not rent land, then the actual price of renting arable land to be paid by farmers in the observed region is applied to land owned. By applying this approach, the influence of the opportunity costs of their own land on the profitability of surveyed family farms was investigated.

By including the opportunity costs of their own resources (arable land owned) in the calculation, it can be seen that the percentage of profitable family farms is significantly reduced. In this case, without state incentives for agriculture surveyed farms are not profitable, whereas with state incentives for agriculture only the farms of the size of over 82.13 ha are profitable. This once again shows the importance of state incentives for agriculture for profitable operations of the surveyed farms. This raises the question whether in the case of the high costs of renting it is better for small farms to rent their land rather than to cultivate it.

Taking all the aforementioned into account, the effect of the price level of renting arable land on the profitability of family farms is examined. Given the current market trends it is unlikely that the costs of renting arable land in the next period will be lower. In this respect, the influence of the increase in the price of renting arable land by $30 \%$ on the profitability of surveyed family farms was examined (Graph 3).

Graph 3. The impact of the price of renting arable land (price rise of 30\%) on the profitability of surveyed family farms.

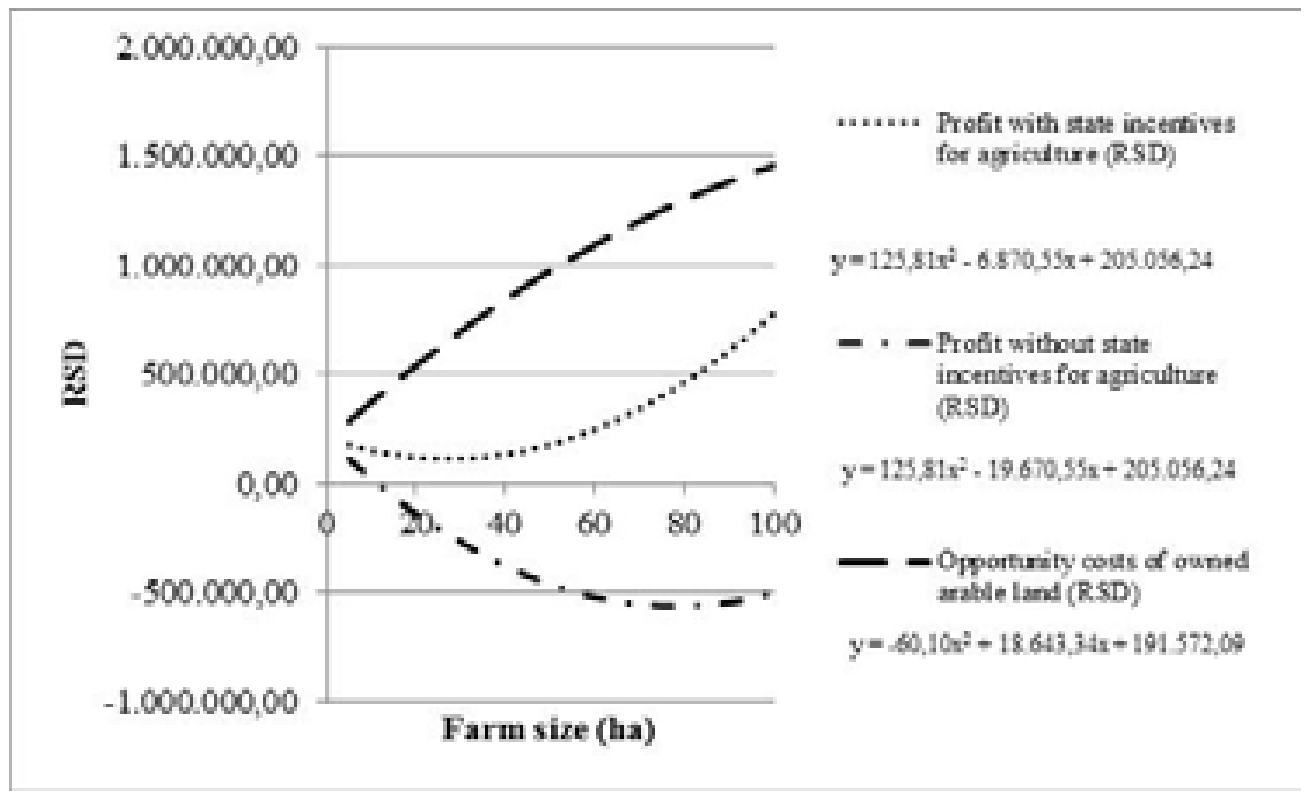

Source: Authors ' calculation based on the survey data

EP 2014 (61) 3 (575-585) 
This shows the importance of state incentives for agriculture for a profitable operation of the surveyed farms. At the same time, it is in line with the research showing that state incentives related to production costs, have an increasingly important role in the operation of family farms directed at crop production (Todorović, 2010; Todorović and Filipović, 2010). Therefore, it is necessary to take this into account when designing agrarian policy in the future period.

It is very important to underline that the number of profitable farms would additionally and significantly decrease if their own resources (arable land owned) were evaluated and this particularly applies to those farms that have a high share of arable land owned in total used arable land (in the case of surveyed farms, these comprise the smallest farms). Bearing this in mind, the assessment of its own production resources, that is, resources owned by a family farm (arable land) was carefully considered because it is difficult to determine the potential income that would be generated by their alternative use. In order to highlight the effect of the opportunity costs, they are separated from other costs.

It was found that in the case of increasing the prices of renting arable land by $30 \%$ without state incentives for agriculture only farms that do not rent land will be profitable, and these are the smallest surveyed farms. However, they will be unprofitable if the opportunity costs of their own land are taken into account. However, with state incentives for agriculture all surveyed farms are profitable even in the case of the increase in the rent of agricultural land by $30 \%$, but only if the opportunity costs of their own land are not taken into account. In the case of taking into account the opportunity costs of their own land, none of the surveyed farms will be profitable even with state incentives for agriculture. This only confirms the previous dilemma, that under the conditions of high costs of renting arable land, it is better to rent the land rather than cultivate it.

\section{Conclusion}

Based on the results of the conducted research, it can be concluded that the increase in the size of family farms and the change in the structure of crop production cause a relatively high rate of the growth in production value and variable costs, as well as a significant decrease in fixed costs (excluding the costs of renting land) per ha of arable land, which affects the profitability of operations. In addition, the analysis of profitability showed a great sensitivity to the presence or absence of state incentives for agriculture. In this respect, family farms that are profitable can cease to be when the state incentives for agriculture are excluded from calculation, which shows the importance the state incentives for agriculture have for profitable business operations of the surveyed farms.

By including the opportunity costs of their own resources (arable land owned) in the calculation of profit, it can be seen that the percentage of profitable family farms is significantly reduced. In this case, without state incentives for agriculture, surveyed farms are not profitable, whereas with state incentives for agriculture only farm of the size of over 82.13 ha are profitable. Furthermore, with state incentives for agriculture all surveyed farms are profitable even with the increase in the rent of agricultural land by $30 \%$, but only if the opportunity costs of their own land are not taken into account. 
The obtained results show that the survival of the majority of smaller family farms directed at crop production without state incentives for agriculture over the long term is called into question, especially if one takes into account the process of joining the EU, and the growing competition in the market.

\section{References}

1. Bartolini, F., Viaggi, D. (2013): The common agricultural policy and the determinants of changes in EU farm size, Land Use Policy, vol. 31, pp. 126-135, doi:10.1016/j. landusepol.2011.10.007

2. Blancard, S., Boussemart, J. P., Briec, W., Kerstens, K. (2006): Short- and long-run credit constraints in French agriculture: adirectional distance function framework using expenditure-constrained profit functions, American Journal of Agricultural Economics, vol. 88(2), pp. 351-364, doi:10.1111/j.1467-8276.2006.00863.x

3. Bogdanov, N., Božić, D. (2005): Promene u posedovnoj i socio-ekonomskoj strukturi zemljoradničkih gazdinstava Srbije tokom perioda tranzicije, u monografiji - Porodična gazdinstava Srbije u promenama, str. 91-109, Poljoprivredni fakultet Univerziteta u Beogradu, Beograd, Republika Srbija.

4. Bogdanov, N., Božić, D., Munćan, P. (2004): Ocena efekata integracije u STO i EU na poljoprivredu Srbije, Ekonomika poljoprivrede, vol. 51, br. 3-4, str. 249-256, Institut za ekonomiku poljoprivrede, Beograd, Republika Srbija.

5. Bojnec, Ц̌., Latruffe, L. (2013): Farm size, agricultural subsidies and farm performance in Slovenia, Land Use Policy, vol. 32, pp. 207-217, doi:10.1016/j. landusepol.2012.09.016

6. Bošnjak, D., Rodić, V. (2011): Zemljišni resursi kao faktor povećanja dohotka porodičnih gazdinstava u AP Vojvodini, Ekonomika poljoprivrede, vol. 58, br. SB-2, str. 63-77, Institut za ekonomiku poljoprivrede, Beograd, Republika Srbija.

7. Bošnjak, D., Rodić, V. (2010): Oranice u Srbiji, kapaciteti, razmeštaj način korišćenja, Poljoprivredni fakultet Univerziteta u Novom Sadu, Novi Sad, Republika Srbija.

8. Božić, D., Munćan, P. (2007): Family Farms - the Factors of Agricultural Development in Serbia, u tematskom zborniku radova - Development of Agriculture and Rural Areas in Central and Eastern Europe, str. 221-230, Društvo agrarnih ekonomista Srbije, Novi Sad, Republika Srbija.

9. Dries, L., Swinnen, J. F. M. (2010): The impact of interfirm relationships on investment: evidence from the Polish dairy sector, Food Policy, vol. 35(2), pp. 121-129, doi:10.1016/j. foodpol.2009.11.005

10. Gogić, P. (2009): Teorija troškova sa kalkulacijama: uproizvodnji i preradipoljoprivrednih proizvoda, Poljoprivredni fakultet Univerziteta u Beogradu, Beograd, Republika Srbija.

11. Munćan, P. (2011): Zavisnost dohotka porodičnih gazdinstava od veličine poseda $i$ strukture ratarske proizvodnje, Ekonomika poljoprivrede, vol. 58, br. SB-2, str. 51-61, Institut za ekonomiku poljoprivrede, Beograd, Republika Srbija. 
12.Munćan P., Božić, D. (2013): The effects of input subsidies on field of crop production in Serbia, Economics of agriculture, vol. 60(3), pp. 585-594, IAE Belgrade.

13. Munćan, P., Božić, D., Bogdanov, N. (2010): Ekonomska efikasnost proizvodnje ratarskih kultura na porodičnim gazdinstvima u AP Vojvodini, Ekonomika poljoprivrede, vol. 57, br. 1, str. 15-24, Institut za ekonomiku poljoprivrede, Beograd, Republika Srbija.

14. Munćan, P., Živković, D., Jevtić, S. (1996): Uticaj proizvodne orijentacije porodičnih gazdinstava ratarskog usemrenja na ekonomske rezultate, u zborniku radova Poljoprivredno domaćinstvo, obnova i razvoj sela, Zavod za sociologiju razvoja sela, Beograd, Republika Srbija.

15. Todorović, S. (2010): Uticaj mera agrarne politike na ekonomski položaj proizvođača kukuruza u Republici Srbiji, Zbornik radova sa konferencije - Prvi naučni simpozijum agronoma sa međunarodnim učešćem „AGROSYM Jahorina 2010“, Jahorina, Bosna i Hercegovina, str. 151-257.

16. Todorović, S., Filipović, N. (2010): Economic analysis of wheat production on family farms, Journal of Agricultural Sciences, vol. 55(1), pp. 79-87.

17. Todorović, S., Filipović, N. (2010): Uticaj mera agrarne politike na ekonomski položaj proizvođača pšenice u Republici Srbiji, u tematskom zborniku radova - Agrarna i ruralna politika 3 - Održivost agroprivrede, zadrugarstva i ruralnih područja, str. 61-68, DAES - Društvo agrarnih ekonomista Srbije i Poljoprivredni fakultet Univerziteta u Beogradu, Beograd, Republika Srbija.

18. Todorović, S., Filipović, N., Munćan, M. (2010): Economic analysis of sunflower production on family farms in the Republic of Serbia, Research Journal of Agricultural Science, vol. 42(3), pp. 833-837. 


\title{
PROFITABILNOST PORODIČNIH GAZDINSTAVA USMERENIH NA RATARSKU PROIZVODNJU ${ }^{5}$
}

\author{
Petar Munćan ${ }^{6}$, Saša Todorovič ${ }^{7}$, Mihajlo Munćan ${ }^{8}$
}

\begin{abstract}
Rezime
Uspešnost u ratarskoj proizvodnji zavisi, s jedne strane, od ostvarenih prinosa $i$ ostvarenih prodajnih cena (vrednosti proizvodnje), is druge strane od učinjenih troškova proizvodnje. Na osnovu ovih podataka dolazi se do različitih ekonomskih pokazatelja kojima se iskazuje uspešnost poslovanja gazdinstva. Podaci o osnovnim parametrima proizvodnje prikupljeni su metodom ankete, koja je sprovođena poslednjih pet godina (2009-2013.) na odabranih 40 porodičnih gazdinstava veličine do 100 ha, razvrstanih u pet grupa, usmerenih isključivo na ratarsku proizvodnju sa područja dve opštine Južnobanatskog okruga. Efikasnost proizvodnje i racionalnost korišćenja raspoloživih resursa posmatranih porodičnih gazdinstava merena je izračunavanjem njihovog profita sa uključivanjem u obračun državnih podsticaja za poljoprivedu $i$ vrednovanjem sopstvenih resursa angažovanih za proizvodnju.
\end{abstract}

Ključne reči: profit, porodično gazdinstvo, ratarska proizvodnja, oportunitetni troškovi.

5 Rad je rezultat istraživanja na projektu Ministarstva prosvete, nauke i tehnološkog razvoja Republike Srbije broj 179028, pod nazivom: „Ruralno tržište rada i ruralna ekonomija Srbije diverzifikacija dohotka i smanjenje ruralnog siromaštva“"

6 Dr Petar Munćan, redovni profesor, Univerzitet u Beogradu, Poljoprivredni fakultet, Nemanjina 6, 11080 Zemun, Republika Srbija, Telefon: +381 112615315 / lok. 413, E-mail: muncan@agrif.bg.ac.rs

7 Saša Todorović, asistent, Univerzitet u Beogradu, Poljoprivredni fakultet, Nemanjina 6, 11080 Zemun, Republika Srbija, Telefon: +381 112615315 / lok. 406, E-mail: sasat@agrif.bg.ac.rs

8 Mihajlo Munćan, asistent, Univerzitet u Beogradu, Poljoprivredni fakultet, Nemanjina 6, 11080 Zemun, Republika Srbija, Telefon: +381 112615315 / lok. 406, E-mail: mmuncan@agrif.bg.ac.rs 